\title{
PENGARUH PROSES PENGINTEGRASIAN PANAS TERHADAP KONVERSI AMONIAK PADA INTERCOOLER REAKTOR AMONIAK DENGAN ANALISIS EKSERGI DAN PINCH
}

\author{
Muhammad Djoni Bustan \\ Program Studi Teknik Kimia, Program Pascasarjana Universitas Sriwijaya, Palembang \\ Jalam Padang Selasa N0.524, Bukit Besar, Palembang 30139 \\ Telp: (0711)352132 - 354222 Fax: (0711) 317202 - 320310 \\ ${ }^{*}$ Penulis korespondensi: djajashanta@yahoo.co.id
}

\begin{abstract}
Abstrak
Amoniak merupakan salah satu senyawa penting yang banyak digunakan dalam industri kimia sebagai bahan baku dan produk. Salah satu unit pabrik amoniak yang dikaji membutuhkan gas alam sebesar 13.627 MMBTU sebagai bahan bakar (fuel) dan 24.570 MMBTU sebagai bahan baku untuk memproduksi 1 ton amoniak cair. Belum optimalnya sistim pendinginan antar unggun (bed) dan belum maksimalnya pemanfaatan panas hasil reaksi di reaktor amoniak menyebabkan konversi reaksi masih rendah. Analisis eksergi yang merupakan kombinasi antara Hukum Termodinamika I dan II, digunakan untuk mengetahui titik- titik kehilangan panas yang paling tinggi, yaitu pada bed 1, bed 2, dan bed 3. Analisis pinch yang diterapkan pada reaktor tersebut dapat dibuat suatu sistem jaringan alat penukar panas yang baru pada ammonia converter, sehingga diperoleh konversi yang lebih baik.
\end{abstract}

Kata kunci: analisis eksergi, analisis pinch, katalis asam, sintesis amoniak

\begin{abstract}
Ammonia is a compound which is important and widely used in chemical industry as raw materials and products. One of the ammonia plant units investigated needs 13,627 MMBTU of natural gas as fuel and 24,570 MMBTU as raw material to produce 1 ton of ammonia in liquid form. The low conversion of ammonia reaction is caused by inefficient inter-bed cooling system and ineffective utilization of heat of reaction in ammonia reactor. Exergy analysis which is a combination of first and second Law of Thermodynamics was used to determine the points of heat losses in bed 1, bed 2 and bed 3. Based on pinch analysis in ammonia convertor, a new heat exchanger system should be installed to obtain a better conversion.
\end{abstract}

Keywords: exergy analysis, pinch analysis, acid catalyst, ammonia

\section{PENDAHULUAN}

Pada industri kimia, salah satu komponen yang mempengaruhi tingginya biaya produksi adalah biaya bahan bakar. Harga bahan bakar meningkat dari tahun ke tahun sehingga mempengaruhi harga jual produk di pasar. Di sisi lain, isu lingkungan hidup menjadi faktor yang juga mempengaruhi biaya produksi, karena adanya kegiatan industri maka akan menghasilkan limbah yang memerlukan suatu instalasi pengolahan limbah.

Industri pupuk merupakan salah satu industri kimia dengan biaya produksi tinggi, sedangkan harga jual relatif rendah. Karena itu pabrik pupuk perlu diintegrasikan dengan pabrik lain, seperti pabrik amoniak yang mampu untuk menunjang pabrik pupuk, baik dari segi penyedian bahan baku maupun menghasilkan produk amoniak yang dapat dijual langsung ke pasar dengan harga jual yang tinggi.

Amoniak yang diproduksi oleh suatu unit yang dipelajari membutuhkan energi yang cukup besar. Untuk memproduksi 1 ton amoniak cair dibutuhkan gas alam 13.617 MMBTU sebagai fuel dan 24.570 MMBTU sebagai bahan baku, dengan total produksi keseluruhan dalam satu hari sebesar 792 ton per hari.

Reaksi pembentukan amoniak terjadi antara gas nitrogen dan hidrogen berlangsung pada temperatur dan tekanan tinggi. Secara termodinamika, semakin tinggi temperatur dan tekanan, maka konversi akan semakin rendah. Reaksi yang terjadi adalah eksotermis 
dimana reaksi menghasilkan panas yang dibuang ke lingkungan.

Pada penelitian ini akan dilakukan studi pengintegrasian panas dari setiap bed sehingga akan dihasilkan suatu pembagian panas dari jaringan alat penukar panas sehingga beban panas di intercooler dapat dikurangi.

\section{ANALISIS EKSERGI DAN PINCH \\ Analisis Eksergi}

Dalam termodinamika eksergi merupakan persilangan antara hukum I dan hukum II termodinamika. Hukum I termodinamika menyatakan bahwa tidak ada energi yang berubah secara kuantitas, tetapi terjadi perubahan energi secara kualitas. Perubahan energi pada sistim sama dengan perubahan energi terhadap lingkungan. Perubahan energi terhadap sistim di rumuskan sebagai :

$$
\Delta \mathrm{U}+\Delta \mathrm{E}_{\mathrm{k}}+\Delta \mathrm{E}_{\mathrm{p}}=\Delta \mathrm{E}
$$

dimana :

$\Delta \mathrm{U}=$ Perubahan energi dalam

$\Delta \mathrm{E}_{\mathrm{K}}=$ Perubahan energi kinetik

$\Delta \mathrm{E}_{\mathrm{p}}=$ Perubahan energi potensial

Perubahan energi terhadap lingkungan $=\mathrm{Q}+\mathrm{W}$

Hukum I termodinamika menitikberatkan perubahan entalpi $(\Delta H)$. Untuk sistem terbuka, hukum I termodinamika didefinisikan sebagai berikut :

$$
\frac{\mathrm{dE}}{\mathrm{dt}}=\sum_{\mathrm{i}=0}^{\mathrm{n}} \mathrm{Q}_{\mathrm{i}}-\mathrm{W}+\sum_{\mathrm{in}} \mathrm{mh}^{0}-\sum_{\text {out }} \mathrm{mh}^{0}
$$

Hukum kedua termodinamika menyatakan bahwa terjadi perubahan dari kualitas tinggi ke kualitas rendah, dalam hal ini terjadi perpindahan dari temperatur tinggi ke temperatur rendah, dan tidak semua panas dapat diubah menjadi kerja, akan ada yang hilang selama proses. Hukum II termodinamika menitikberatkan pada perubahan entropi $(\Delta S)$ dalam bentuk persamaan dirumuskan :

$$
\mathrm{S}_{\text {gen }}=\frac{\mathrm{dS}}{\mathrm{dt}}-\sum_{\mathrm{i}=0}^{\mathrm{n}} \frac{\mathrm{Q}_{\mathrm{i}}}{\mathrm{T}_{\mathrm{i}}}-\sum_{\text {in }} \mathrm{ms}+\sum_{\text {out }} \mathrm{ms} \geq 0
$$

Eksergi sendiri didefenisikan sebagai energi yang dikoreksi oleh faktor lingkungan dengan menitikberatkan pada faktor koreksi entropi. Eksergi juga dapat didefinisikan sebagai kerja maksimum yang dihasilkan dari sistem yang dipengaruhi oleh lingkungan sekitar sehingga terjadi kesetimbangan. Persamaan umum eksergi yang merupakan persilangan antara hukum I dan hukum II termodinamika adalah sebagai berikut :

$$
\mathrm{E}_{\mathrm{x}}=\left(\mathrm{H}-\mathrm{H}_{0}\right)-\mathrm{T}_{0}\left(\mathrm{~S}-\mathrm{S}_{0}\right)
$$

Persamaan umum neraca eksergi adalah :

Eksergi masuk $=$ Eksergi keluar

dimana :

$$
\mathrm{Ex}_{\text {in }}+\mathrm{Ex}_{\text {gen }}=\mathrm{Ex}_{\text {out }}+\mathrm{Ex}_{\mathrm{acc}}+\mathrm{Ex}_{\text {loss }}
$$

$\mathrm{Ex}_{\text {in }}=\mathrm{Ex}_{\text {out }}=\mathrm{Ex}_{\text {fisika }}$

$$
=\left(\mathrm{H}-\mathrm{H}_{0}\right)-\mathrm{T}_{0} \cdot\left(\mathrm{S}-\mathrm{S}_{0}\right)
$$

$$
\begin{gathered}
\mathrm{Ex}_{\text {gen }}=\mathrm{Ex}_{\text {kimia }}=\sum_{\mathrm{i}=1}^{\mathrm{n}}\left(\mu_{\mathrm{i}}-\mu_{0, \mathrm{i}}\right) \mathrm{x}_{\mathrm{i}} \\
\mathrm{Ex}_{\text {loss }}=\mathrm{T}_{0} \cdot \mathrm{S}_{\text {gen }}
\end{gathered}
$$

Untuk kondisi yang steady state, maka eksergi akumulasi $=0$.

\section{Analisis Pinch}

Yang dimaksud dengan pinch technology adalah suatu metodologi yang didasarkan pada prinsip-prinsip termodinamika untuk mengurangi pemakaian energi pada overall suatu proses. Teknologi pinch digunakan untuk merancang dan mengembangkan jaringan alat penukar panas, dengan mengintegrasikan aliran panas (sebagai sumber panas) dengan aliran dingin (sebagai penyerap panas). Tujuan yang ingin dicapai adalah pemanfaatan panas yang ada di dalam aliran proses semaksimal mungkin atau penggunaan energi seminimal mungkin. Hasil analisa dengan teknologi pinch, mulai diaplikasikan didalam industri pada tahun 1980-an.

Tahap awal pada analisis pinch adalah diketahuinya neraca massa dan neraca panas pada suatu peralatan/proses, sehingga dapat tentukan peluang-peluang utama (target) untuk penghematan energi dan selanjutnya dibuat suatu disain dari Heat Exchanger Network (HEN).

Perancangan dengan teknik pinch ini akan mampu menentukan target energi, yaitu energi minimum yang seharusnya diperlukan pada suatu jaringan alat penukar panas. Alat bantu yang dipergunakan dalam teknologi pinch adalah diagram grid, tabel masalah (problem table), kurva composite, dan kurva grand composite.

Untuk menganalisis pinch pada suatu peralatan, ada dua data yang menjadi acuan utama, yaitu data dari flowsheet dan data-data thermal. Data pada flowsheet menunjukkan deskripsi proses keseluruhan, sedangkan data thermal menunjukkan data-data pada suatu jaringan heat exchanger. Dari data thermal akan diperoleh suatu target untuk konsumsi energi minimum, dengan ditunjukkan dalam suatu composite curve.

Pada setiap analisis pinch diperlukan prosedur dan langkah pengerjaan yang berkesinambungan. Secara umum, tahap-tahap analisis pinch adalah mengikuti langkah-langkah berikut :

1. Identifikasi aliran pada proses.

Aliran fluida di dalam proses dibagi menjadi 3 (tiga) yaitu aliran fluida panas (hot fluid), aliran fluida dingin (cold fluid), dan aliran fluida utilitas.

2. Mengolah data-data termodinamika.

Untuk analisis pinch, data-data termodinamika yang paling penting adalah temperatur fluida $(\mathrm{T})$ dan entalpi $(\Delta \mathrm{H})$.

3. Pemilihan beda temperatur pertukaran panas minimum $\left(\Delta \mathrm{T}_{\min }\right)$ antara fluida panas dan fluida dingin.

4. Pembuatan diagram Cascade. 
Kurva menggunakan alokasi entalpi pada setiap aliran sehingga menghasilkan kebutuhan utilitas panas atau utilitas dingin yang ada dalam proses.

5. Pembuatan kurva composite dan grand composite. Kurva composite adalah kurva antara temperatur dengan entalpi. Kurva ini terdiri dari temperatur pada sumbu ordinat dan entalpi apada sumbu absis. Profil kurva ini menggambarkan panas yang ada di dalam proses, $\mathrm{Q}_{\mathrm{H}}$, dan panas yang diperlukan pada proses, $Q_{C}$. Dari kurva ini juga di dapat temperatur Pinch yang menunjukkan tidak adanya perpindahan panas dari fluida panas dengan fluida dingin konsiderasi temperatur fluida yang bersangkutan

Kurva grand composite menunjukkan variasi suplai dan kebutuhan panas yang ada di dalam proses. Diagram inipun berguna untuk memilih jenis utilitas yang diperlukan dalam proses. Penggunaan kurva ini bertujuan untuk memaksimalkan tingkat utilitas yang dinilai lebih murah biaya operasinya.

Untuk memahami prinsip pinch itu sendiri, maka keyword yang perlu diperhatikan (Linhoff et al., 1982):

- Panas yang ditransfer harus menyeberangi pinch point.

- Tidak ada penambahan utilitas dingin di atas pinch point

- Tidak ada penambahan utilitas panas di bawah pinch point

Dari keseluruhan tahapan dalam analisis pinch salah satu hal penting yang menjadi kunci utama teknologi pinch, adalah kurva composite. Kurva composite merupakan kurva yang terbentuk antara temperatur $(\mathrm{T})$ dengan enthalpi $(\mathrm{H})$ atau lebih dikenal dengan diagram T-H. Kurva ini menunjukkan profil panas yang tersedia pada suatu proses (hot composite curve) dan panas yang dibutuhkan pada suatu proses (cold composite curve), yang digambarkan dalam suatu diagram yang sama.

Kurva composite dapat memprediksi target kebutuhan utlitas panas dan utilitas dingin, arah perpindahan panas, dan menempatkan panas yang yang dapat direcover seperti ditunjukkan pada gambar berikut.. Untuk menggambarkan jaringan alat penukar kalor di dalam konfigurasi proses, maka digunakan diagram grid untuk menggambarkan jaringan alat penukar panas (Heat Exchanger Network). Jaringan alat penukar kalor ini terdiri dari dua bagian yaitu aliran panas dan aliran dingin. Aliran panas merupakan aliran proses yang membutuhkan pendinginan, sedangkan aliran dingin adalah aliran yang membutuhkan pemanasan. Aliran panas terletak pada bagian atas, mengalir dari kiri ke kanan dan aliran dingin terletak pada bagian bawah, mengalir dari kanan ke kiri. Diagram ini juga memprediksi kemungkinan cross pinch yang memungkinkan terjadinya perpindahan panas dari seksi di atas pinch (above pinch point) ke seksi di bawah pinch (below pinch point), seperti ditunjukkan pada Gambar 1.

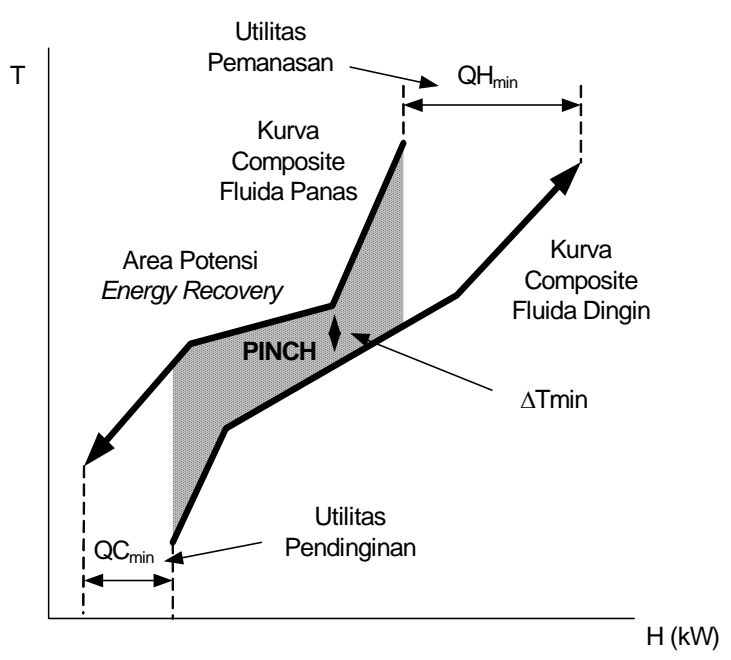

Gambar 1. Kurva composite

Kurva grand composite dibentuk berdasarkan penggunaan data-data aliran pada kurva composite dan utilitas, kurva ini akan menghasilkan data tentang kapasitas sumber utilitas dan target utilitas yang harus dipenuhi oleh proses. Sebagai langkah awal dalam pembuatan kurva grand composite adalah pembuatan kurva composite. Gambar 2 menunjukkan kurva composite dan grand composite dari suatu proses yang telah mengalami modifikasi proses dimana kurva cold composite akan bergeser dengan perubahan temperature naik $1 / 2$ dari $\Delta \mathrm{T}_{\min }$ dan hot composite akan bergeser dengan perubahan temperatur turun $1 / 2$ dari $\Delta \mathrm{T}_{\text {min }}$. Dengan kata lain, kurva ini menunjukkan pengurangan pendekatan temperatur yang diijinkan pada fluida panas, sedangkan aliran dingin merupakan penambahan temperatur yang diijinkan. Hasilnya nanti akan berdasarkan temperatur proses yang memiliki pendekatan temperatur $\left(\Delta \mathrm{T}_{\min }\right)$. Perubahan temperatur dari aliran proses dan level utilitas terjadi ketika level utilitas menyentuh kurva grand composite. Kurva grand composite dibentuk dari entalpi sebagai absis (sumbu x) dan temperatur (sumbu y)

Dapat diilustrasikan pada gambar di bawah ini, bahwa perlunya untuk mensuplai utilitas panas level temperatur tertinggi. Kurva grand composite menunjukkan bahwa utilitas panas dapat disuplai dari dua level temparatur $\mathrm{TH}_{1}$ (Uap Tekanan Tinggi) dan $\mathrm{TH}_{2}$ (Uap Tekanan Rendah). Total kebutuhan utilitas panas minimum adalah $\mathrm{Qh}_{\min }=\mathrm{H}_{1}+\mathrm{H}_{2}$. Demikian juga dengan kebutuhan utilitas dingin $\mathrm{Qc}_{\min }=\mathrm{C}_{1}$ (Refrigan) $+\mathrm{C}_{2}$ (Air Pendingin). Titik $\mathrm{TH}_{2}$ dan $\mathrm{TC}_{2}$ dimana $\mathrm{H}_{2}$ dan $\mathrm{C}_{2}$ menyentuh kurva grand composite disebut 'Utility Pinch', seperti diilustrasikan dalam Gambar 2. 


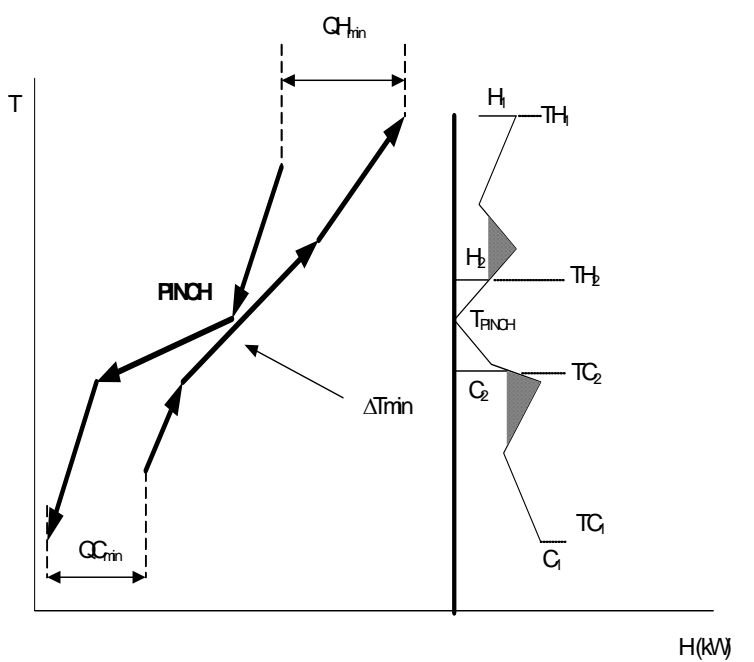

Gambar 2. Kurva grand composite

\section{METODE PENELITIAN}

Dalam studi ini, analisis pinch yang mempunyai kekuatan untuk menyajikan informasi sistem dengan menggunakan diagram-diagram yang sederhana (seperti kurva composite dan kurva grand composite) dan memberikan target-target energi sebelum perancangan rinci dikombinasikan dengan kekuatan analisis eksergi yang dapat memberikan pengertian yang mendalam mengenai proses-proses dan dapat mengidentifikasi penyebab-penyebab nirefisiensi termodinamis untuk mendapatkan suatu metoda yang lebih baik.

Analisis eksergi digunakan untuk mengidentifikasikan kemungkinan-kemungkinan untuk optimisasi energi lebih lanjut pada pabrik pupuk. Untuk Instalasi yang telah ada, cara yang paling cepat dan paling mudah adalah memeriksa paduan-paduan (matches) yang ada untuk melihat apakah kebutuhan pemananasan dapat dikurangi dengan langkah-langkah yang sederhana. Untuk itu, jaringan penukar panas yang telah ada diperiksa apakah melanggar kaidah-kaidah pinch. Identifikasi sederhana pada penukar panas yang melanggar kaidahkaidah pinch dapat dibuat jika jaringan penukar panas tersedia dalam bentuk grid diagram dan pinch diindikasikan pada diagram ini.

Analisis eksergi didasarkan pada perhitungan eksergi kimia dan eksergi termo-mekanikal dari semua aliran material dan juga eksergi dari semua aliran energi. Variabel-variabel keadaan dari ligkungan (temperatur dan tekanan) dipilih sesuai dengan kondisi setempat. Komposisi udara yang disederhanakan dipilih sebagai komposisi kimia dari lingkungan. Selanjutnya fraksi mol dan eksergi kimia dari komponen-komponen lingkungan dan komponenkomponen penting lainnya dapat ditentukan. Sifat-sifat fisik dari arus-arus (streams) material ditentukan sehingga eksergi dari arus-arus material dapat dihitung. Selanjutnya, semua aliran massa, aliran energi dan aliran eksergi yang masuk dan keluar instalasi disetimbangkan.
Studi pengintegrasian panas ini secara garis besarnya akan dibagi dalam tiga tahapan utama, yaitu evaluasi proses-proses saat ini untuk mengidentifikasi kehilangan energi, evaluasi proses yang dimodifikasi untuk mendapatkan alternatif-alternatif yang mungkin untuk mengurangi konsumsi energi, dan perancangan jaringan penukar panas untuk mencapai target tersebut.

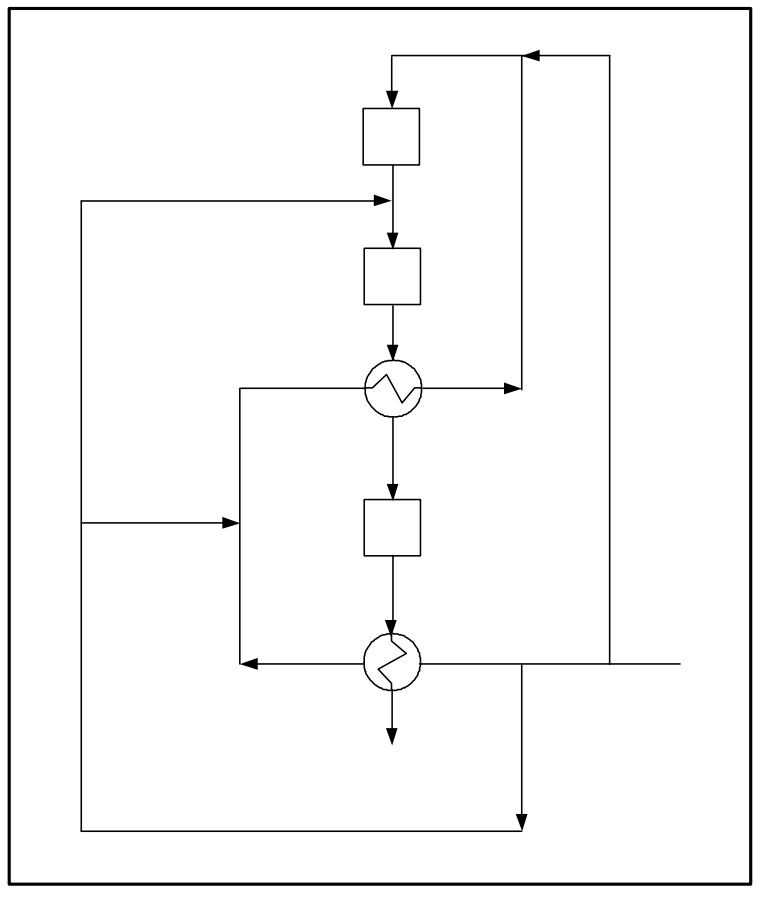

Gambar 3. Skema jaringan alat amoniak konverter Existing Design

Sebagai langkah awal pada tahap pertama ini adalah analisa data dari tiap proses untuk mengidentifikasi kehilangan-kehilangan energi. Secara garis besar, langkah-langkah yang akan dilaksanakan pada tahap ini untuk masing-masing proses yang terdapat pada jaringan adalah sebagai berikut:

a. Menggambarkan diagram alir untuk masingmasing proses hanya menggunakan peralatanperalatan yang utama saja.

b. Memplotkan kondisi-kondisi operasi saat ini, yaitu:

- Komposisi feed masuk reaktor

- Kondisi operasi gas quench, di antara bed.

- Kondisi operasi di setiap bed konverter amoniak (tekanan dan temperatur), serta karakteristik katalis.

- Kondisi operasi di interchanger dan bottom exchanger di antara bed.

- Konversi produk yang dihasilkan.

c. Perhitungan neraca massa setiap bed.

d. Perhitungan neraca panas di setiap bed, interchanger dan bottom exchanger.

e. Perhitungan neraca eksergi di setiap bed.

f. Neraca eksergi di interchanger.

g. Neraca eksergi di bottom exchanger. 
Hasil dari perhitungan-perhitungan ini untuk mengidentifikasi peluang-peluang untuk memaksimalkan peningkatan proses. Dari data-data yang dihasilkan, maka dapat dibuat grand composite curve. Dari kurva tersebut, dapat diidentifikasi titiktitik dimana terdapat kehilangan energi yang signifikan.

Setelah titik-titik kehilangan energi yang signifikan teridentifikasi, maka selanjutnya akan dilakukan modifikasi-modifikasi dengan melakukan reposisi aliran fluida di dalam proses. Proses-proses yang telah dimodifikasi selanjutnya akan dievaluasi evaluasi untuk mendapatkan alternatif-alternatif yang dapat mengurangi kehilangan energi dengan mengulangi langkah-langkah seperti pada identifikasi proses, sehingga akhirnya diperoleh suatu usulan proses baru dengan kondisi yang optimal dan dapat memberikan konversi yang proporsional.

Setelah modifikasi proses yang berpotensi untuk meningkatkan pemanfaatan ulang kalor diperoleh, langkah selanjutnya adalah merancang jaringan pemanfaatan ulang panas secara sitematis untuk mencapai target yang telah ditetapkan tersebut.

\section{HASIL DAN PEMBAHASAN Integrasi Panas Sistim Intercooler pada Ammonia Converter 105 DA}

Faktor temperatur dan tekanan di dalam ammonia converter mempengaruhi konversi produk pada pagi, siang dan malam hari. Pada pagi hari, temperatur udara akan beranjak naik dan berada pada range $25-30^{\circ} \mathrm{C}$. Pada sore hari dan malam hari, temperatur lingkungan beranjak turun. Tidak stabilnya kondisi lingkungan pada waktu pagi, sore dan malam hari akan mempengaruhi eksergi pada pagi, sore dan malam hari.

Pada skema awal dari proses, temperatur yang keluar dari bed $-1\left(482,9^{\circ} \mathrm{C}\right)$, temperaturnya diturunkan terlebih dahulu sebelum masuk ke bed-2 sebagai feed. Pendinginan pada aliran keluar bed-1 dilakukan secara langsung dengan dengan gas quench yang berasal dari aliran feed masuk reaktor pada temperatur $133^{\circ} \mathrm{C}$. Konversi yang terbentuk pada bed-1 secara disain adalah $16.91 \%$. Eksergi yang hilang ke lingkungan sebesar -19.838.232,367 KJ.

Pada bed 2, temperatur keluar bed-2 $\left(464,7^{\circ} \mathrm{C}\right)$ diturunkan temperaturnya sebelum menjadi feed di bed-3 hingga mencapai $384^{\circ} \mathrm{C}$. Pendinginan terjadi di interchanger dimana interchanger ini juga berfungsi untuk memanaskan feed sebelum masuk bed-1. Konversi pada bed-2 turun dibandingkan konversi pada bed-1 yaitu $8,48 \%$. Hal ini dapat terjadi karena temperatur masuk dan keluar bed-2 lebih tinggi dibandingkan pada bed-1.

Eksergi yang hilang ke lingkungan sebesar 12.350.053 KJ. Pada bed-3, aliran keluar bed-3 didinginkan kembali di bottom exchanger hingga temperatur produk mencapai $338,3^{\circ} \mathrm{C}$. Konversi pada bed-3 adalah 10,08\%. Neraca massa, neraca panas, neraca eksergi total seperti ditunjukkan pada tabel berikut :

Tabel 1. Neraca massa total di ammonia converter (105 DA)

\begin{tabular}{lrrrr}
\hline \multirow{2}{*}{ KOMP. } & \multicolumn{2}{c}{ INPUT } & \multicolumn{2}{c}{ OUTPUT } \\
\cline { 2 - 5 } & \multicolumn{1}{c}{ Kmol } & \multicolumn{1}{c}{$\mathrm{Kg}$} & \multicolumn{1}{c}{ Kmol } & \multicolumn{1}{c}{$\mathrm{Kg}$} \\
\hline $\mathrm{CH}_{4}$ & 546,485 & $8.743,760$ & 546,485 & $8.743,760$ \\
$\mathrm{H}_{2}$ & $5.260,085$ & $10.520,170$ & $3.767,006$ & $7.534,013$ \\
$\mathrm{~N}_{2}$ & $1.750,940$ & $49.026,320$ & $1.253,247$ & $35.090,920$ \\
$\mathrm{Ar}$ & 248,745 & $9.949,800$ & 248,745 & $9.949,800$ \\
$\mathrm{NH}_{3}$ & 173,045 & $2.941,765$ & $1.168,431$ & $19.863,322$ \\
\hline TOTAL & $7.979,300$ & 81181,815 & $6.983,914$ & $81.181,815$ \\
\hline
\end{tabular}

Tabel 2. Neraca Panas di Ammonia Converter (105 DA)

\begin{tabular}{clc}
\hline & \multicolumn{1}{c}{ INPUT $(\mathrm{KJ})$} & OUTPUT $(\mathrm{KJ})$ \\
\hline BED -1 & $\mathrm{Q}=62.805 .297,702$ & $\mathrm{Q}=87.200 .990,068$ \\
& $\mathrm{Q}_{\mathrm{R}}=24.395 .692,367$ & \\
BED -2 & $\mathrm{Q}=92.773 .947,155$ & $\mathrm{Q}=107.832 .788,596$ \\
& $\mathrm{Q}_{\mathrm{R}}=1.505 .8841,441$ & \\
BED -3 & $\mathrm{Q}^{2}=86.857 .655,563$ & $\mathrm{Q}=97.369 .935,078$ \\
& $\mathrm{Q}_{\mathrm{R}}=10.512 .279,515$ & \\
HE - 1 & $\mathrm{Q}_{\mathrm{S}}=107.832 .788,596$ & $\mathrm{Q}_{\mathrm{S}}=86.857 .655,563$ \\
& $\mathrm{Q}_{\mathrm{T}}=41.488 .568,400$ & $\mathrm{Q}_{\mathrm{T}}=62.463 .701,433$ \\
HE-2 & $\mathrm{Q}_{\mathrm{S}}=16.909 .055,224$ & $\mathrm{Q}_{\mathrm{S}}=40.037 .380,315$ \\
& $\mathrm{Q}_{\mathrm{T}}=97.369 .935,078$ & $\mathrm{Q}_{\mathrm{T}}=74.241 .609,987$ \\
\hline
\end{tabular}

Tabel 3. Neraca Eksergi di Ammonia Converter (105 DA)

\begin{tabular}{lll}
\hline & \multicolumn{1}{c}{ INPUT (KJ) } & \multicolumn{1}{c}{ OUTPUT (KJ) } \\
\hline BED -1 & $\mathrm{Ex}=32.398 .165,228$ & $\mathrm{Ex}=52.236 .937,595$ \\
& $\mathrm{Ex}_{\mathrm{ch}}=-0,00433$ & $\mathrm{Ex}_{1}=-19.838 .232,367$ \\
BED -2 & $\mathrm{Ex}=51.179 .002,128$ & $\mathrm{Ex}=63.529 .054,961$ \\
& $\mathrm{Ex}_{\mathrm{ch}}=-0,008845$ & $\mathrm{Ex}_{1}=-12.350 .052,833$ \\
BED -3 & $\mathrm{Ex}=46.789 .332,830$ & $\mathrm{Ex}=55.342 .888,990$ \\
& $\mathrm{Ex}_{\mathrm{ch}}=-0,01116$ & $\mathrm{Ex}_{1}=-8.553 .556,200$ \\
HE 1 & $\mathrm{Ex}_{\mathrm{SH}}=63.529 .054,961$ & $\mathrm{Ex}_{\mathrm{SH}}=46.789 .332,830$ \\
& $\mathrm{Ex}_{\mathrm{T}}=18.116 .844,480$ & $\mathrm{Ex}_{\mathrm{T}}=33.507 .556,331$ \\
HE 2 & $\mathrm{Ex}_{\mathrm{SH}}=4.288 .151,393$ & $\mathrm{Ex}_{1}=1.349 .010,279$ \\
& $\mathrm{Ex}_{\mathrm{T}}=55.342 .888,991$ & $\mathrm{Ex}_{\mathrm{T}}=37.4393 .772,911$ \\
& & $\mathrm{Ex}_{1}=4.257 .808,760$ \\
\hline
\end{tabular}

Dari neraca panas dan neraca eksergi terlihat bahwa perbedaan yang cukup signifikan antara energi dan eksergi. Dimana nilai energi sebenarnya merupakan kerja yang tersedia dan termanfaatkan (available work) untuk mengkonversikan reaktan menjadi produk seperti ditunjukkan pada neraca eksergi, yang telah dikoreksi oleh temperatur lingkungan sekitar. Sedangkan energi yang tidak termanfaatkan (lost available work/lost exergy) hilang ke lingkungan sekitar proses.

Dari neraca eksergi ini pula terlihat titik-titik kehilangan eksergi (lost eksergi) yang paling besar berada pada bed-1. Sehingga dari identifikasi awal ini dapat diketahui titik-titik kemungkinan panas yang dapat diintegrasi. Dengan tujuan untuk menjaga temperatur masuk setiap bed agar didapatkan konversi yang proporsional. 
Dari identifikasi awal proses, dapat dibuat suatu tinjauan analisis pinch sebagai pemecahan masalahnya. Sebagai langkah awal dalam tinjauan analisis pinch ini adalah kurva composite dan kurva grand composite, dimana dari kurva composite dan grand composite dapat diketahui kebutuhan dari utilitas panas dan utilitas dingin dari jaringan alat penukar panas.

Dari skema awal sebelum dimodifikasi di dapat kurva grand composite untuk $\Delta \mathrm{T}=5^{\circ} \mathrm{C}, \Delta \mathrm{T}=10^{\circ} \mathrm{C}$, $\Delta \mathrm{T}=15^{\circ} \mathrm{C}, \Delta \mathrm{T}=20^{\circ} \mathrm{C}$.

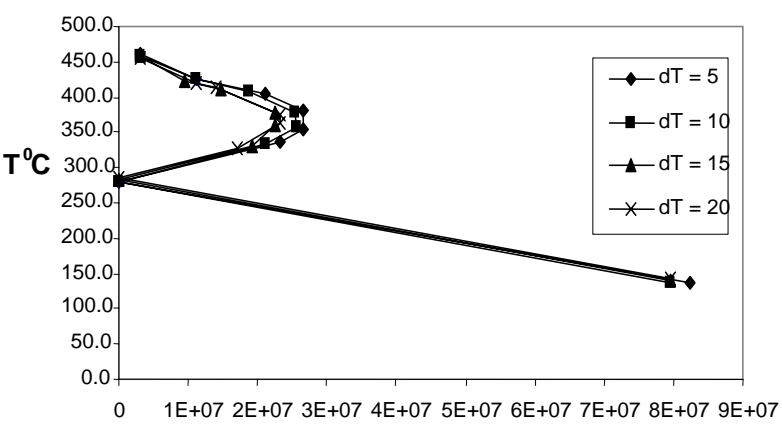

H kumulatif (KJ)

Gambar 4. Kurva grand composite untuk $\Delta \mathrm{T}=5^{\circ} \mathrm{C}, \Delta \mathrm{T}=10^{\circ} \mathrm{C}, \Delta \mathrm{T}=15^{\circ} \mathrm{C} \Delta \mathrm{T}=20^{\circ} \mathrm{C}$

Dari kurva grand composite pada Gambar 4 terlihat bahwa untuk suplai pada hot utilitas pada masing-masing temperatur adalah sama yaitu sebesar $3,02 \times 10^{6}$ KJ. Sedangkan untuk suplai ke utilitas dingin bervariasi, dimana suplai yang paling tinggi berada pada $\Delta \mathrm{T}=5^{\circ} \mathrm{C}$, seperti ditunjukkan pada Gambar 5 dan Gambar 6. Sehingga untuk membuat jaringan yang baru dianalisa pada $\Delta \mathrm{T}=5^{\circ} \mathrm{C}$.

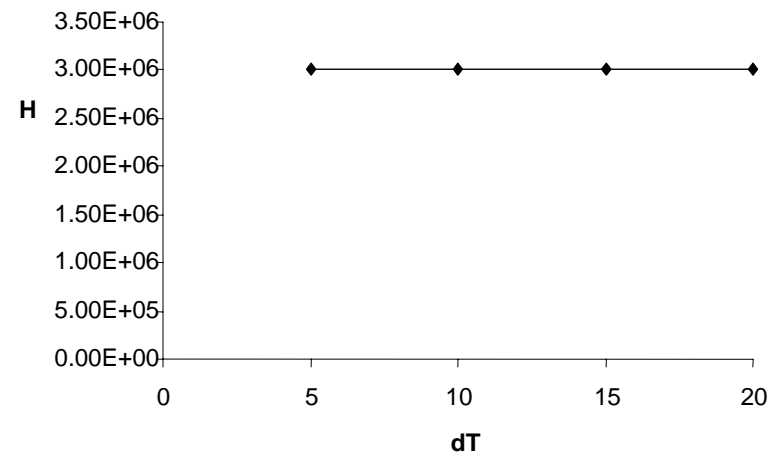

Gambar 5. Suplai dari utilitas panas untuk masingmasing $\Delta \mathrm{T}$

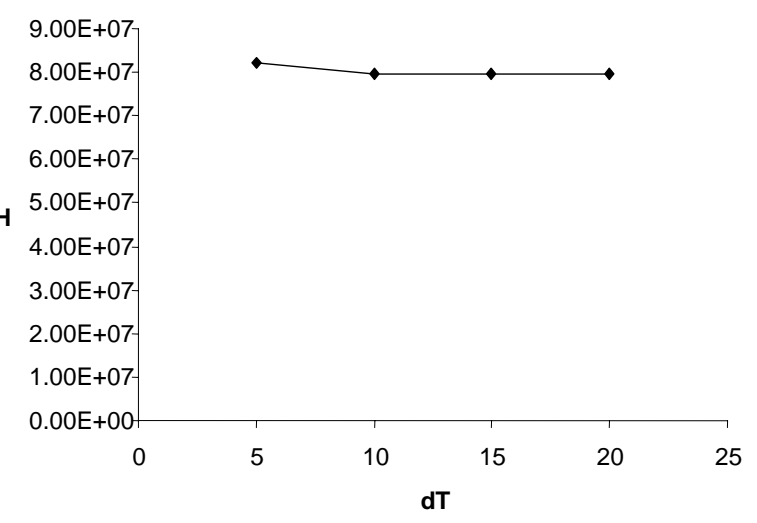

Gambar 6. Suplai panas ke utilitas dingin untuk masing-masing $\Delta \mathrm{T}$

\section{KESIMPULAN}

Dari analisis eksergi dan analisis pinch di dapat kesimpulan bahwa dari analisis eksergi diketahui bahwa titik-titik kehilangan panas yang paling tinggi terdapat pada setiap bed, hal ini disebabkan karena terlalu beratnya beban heat exchanger di antara bed sehingga temperatur masuk di setiap bed tidak dapat konstan.

Dengan adanya jaringan alat penukar yang telah dimodifikasi maka beban heat exchanger dapat dikurangi dan temperatur masuk setiap bed dapat di jaga konstan.

Akibat pengaruh temperatur lingkungan yang berbeda pada saat pagi, sore dan malam hari, maka konversi akan bervariasi dimana konversi amoniak yang paling tinggi terjadi pada pagi hari, dimana pada waktu pagi kehilangan eksergi lebih rendah sehingga konversi lebih besar dibandingkan pada waktu siang dan malam hari.

\section{DAFTAR PUSTAKA}

Ahern, J.E., (1980), The Exergy Method of Energy System Analysis, A Wiley Interscience Publication", Jhon Wiley and Sons, New York.

Alberty, R.A., (1979), Kimia Fisika II, edisi kelima, Penerbit Erlangga.

Anonim, (1998), Operating Instructions Manual PUSRI II, PT. Pupuk Sriwidjaja, Palembang.

Bejan, A., (1988), Advanced Engineering Thermodynamics, Jhon Wiley and Sons.

Cornelissen, R.L., (1997), Thermodynamics and Sustainable, Development, Enschede, Netherlands.

Felder, R.M. and Rouseau, R.W., (1997), Elementary Principles of Chemical Processes, second edition, Jhon Wiley and Sons. 
Hinderink, A.P., Kerkhof, F.P.J.M., Lie A.B.K, Arrons, D.S., and van der Kooi, (1994), Exergy Analysis with A Flowsheeting Simulator-I. Theory: Calculating Exergies of Material Stream, Chem. Eng. Science, vol 51. No.20, pp 4693-4700, Elsevier Science Ltd.

Hinderink, A.P., Kerkhof, F.P.J.M., Lie A.B.K, Arrons, D.S., and van der Kooi, (1994), Exergy Analysis with A Flowsheeting Simulator-II.Aplication: Synthesis Gas Production From Natural Gas, Chem. Eng. Science, vol 51. No.20, pp 4701-4715, Elsevier Science Ltd

Hougen, O.A., Watson, K.M., and Ragartz, R.A., (1959), Chemical Process Principles, Part II: Thermodynamics, second edition, John Wiley \& Sons.

Kotas, T.J., (1986), Exergy Method of Thermal and Chemical Plants, Chem. Eng. Res. Des, vol. 64, May.

Lovegrove, K., Luzzi A., McCann M., and Freitag, O., (1999), Exergy Analysis of Ammonia-Based Solar Thermochemical Power Systems, Solar Energy, vol.66, No. 2, pp. 103-115, Elsevier Science Ltd.

March, L., (1998), Introduction to Pinch Technology, Targeting House Gadbrook Park Northwich, Cheshire CW 7UZ, England.

Perry, R.H. and Green, D., (1984), Perry's Chemical Engineers Handbook, edisi keenam, McGraw Hill Book Company.

Radgen, P., (1996), Pinch and Exergy Analysis of a Fertilizer Complex, part 1, Nitrogen, no. 224.
Radgen, P., (1997), Pinch and Exergy Analysis of a Fertilizer Complex, part 2, Nitrogen, no. 225.

Rastogi, R.P. and Misra, R.R., (1978), An Introduction to Chemical Thermodynamics, first edition, Vikas Publishing House, PVT Ltd, New Delhi.

Raskovic, P., Gradimir I., Radojkovic, N., Mica, V., Goran, W., and Dragan, K., (2002), Process Integration-Exergy Loses of the Heat Exchanger Network, Facta Universitatis, series: Mechanical Engineering, vol 1, pp 1253-1261.

Reid, R.C., Prausnitz, J.M., and Sherwood, T.K., (1991), Sifat gas dan Zat Cair, edisi ketiga, PT. Gramedia Pustaka Utama, Jakarta.

Smith, R., (1995), Chemical Process Design, Mc. Graw Hill Companies Inc., International edition.

Shukuya, M. and Hammache, A., (2002), Introduction to the Concept of Exergy-for a Better Understanding of Low-Temperature-Heating and High-TemperatureCooling System, Submitted.

Smith, J.M and Van Ness, H.C., (1996), Introduction to Chemical Engineering Thermodynamics, fifth edition, The McGraw-Hill Companies Inc.

Wall, G. and Gong, M., (1996), Exergy Analysis versus Pinch Technology, ECOS'96, Stocholm, Swedia.

Wall, G., (1986), Exergy- A Useful Concept, Physical Resource Theory Group, edisi ketiga, Goteborg. 